\title{
10
}

\section{Suppression Subtractive Hybridization Technology}

\author{
Isik G. Yulug and Arzu Atalay
}

\section{Introduction}

It is important to understand where and when each gene is expressed when trying to identify gene function. Although there have been many studies to determine which genes are preferentially expressed in a particular cell or tissue, it has been difficult until recent years to evaluate differences concerning the whole genome. We are now able to study gene expression at the wholegenome level by using modern techniques.

Alterations in gene expression lie at the root of many human diseases and normal and abnormal processes. These alterations can be studied with many different methods including display differential, serial analysis of gene expression (SAGE) (Ye, 2004), representational difference analysis (RDA), gene expression microarrays, and suppression subtractive hybridization ( $\mathrm{SSH}$ ). All of these methods are useful in comparing and identifying differentially expressed genes between two populations. Subtractive hybridization is a frequently used and attractive method for enriching differentially expressed genes. The method was first described in the early 1980 s to create complementary deoxyribonucleic acid (cDNA) libraries (Sargent and Dawid, 1983) and generate probes (Davis et al., 1984) of differentially expressed genes. Originally a large quantity of messenger ribonucleic acid (mRNA) was required to drive hybridization to completion and it was difficult to clone the minute amount of DNA that remained after hybridization, limiting the method's usefulness. However, the method was improved greatly when Duguid and Dinauer (1990) adapted generic linkers to cDNA, which allowed the selective polymerase chain reaction (PCR) amplification of tester cDNA between hybridization cycles. Diatchenko et al. $(1996,1999)$ then introduced the technique of SSH PCR, where it was possible to normalize and enrich the differentially expressed genes more than 1000 -fold in a single round of hybridization. With Clontech's introduction of the commercial PCR-Select cDNA Subtraction Kit (Clontech Laboratories, Palo Alto, CA), SSH rapidly became a popular method in biologic research and took its rightful place in the molecular biologist's armamentarium (Atalay et al., 2002; Li et al., 2001; Liu et al., 2002; Stassar et al., 2001; Uchijima et al., 2001). The SSH technology is a PCR-based cDNA subtraction method and can be used to compare two mRNA populations and obtain cDNAs of genes that are either overexpressed or exclusively expressed in one population compared to another. Genes up-regulated in one sample (referred to as tester) relative to the other sample (called the driver) can be identified. The technique has the advantage of isolating expressed sequences without prior knowledge of their sequence, and its use does not require specialized equipment or 
analyses other than those commonly used with molecular biology techniques (Desai et al., 2000).

Subtractive hybridization has been applied successfully to clone cDNA sequences that are expressed differentially in two cDNA populations (Hedrick et al., 1984; Sargent and Dawid, 1983; Wang and Brown, 1991). The method is designed to selectively amplify differentially expressed transcripts and suppress the amplification of abundant transcripts at the same time; it also normalizes the target transcripts to approximately equal abundance. It thus eliminates the need to separate single- and double-stranded molecules.

\section{The Principle of Suppression Subtractive Hybridization}

SSH (Diatchenko et al., 1996) is a recently developed technique. The basic principle of the SSH method combines normalization of abundant and rare cDNAs with efficient subtraction of common cDNAs between two populations. It is based on the specific suppression PCR that allows for the exponential amplification of differentially expressed genes and suppression of equally expressed genes. This technique is widely used to compare the gene expression profile of two tissues or cell populations. Figure 18 shows the schematic diagram of the SSH procedure. mRNA from both populations are converted to cDNA. The cDNA population, which contains the differentially expressed transcripts, is named "tester" (cDNA1), and the reference cDNA population is named "driver" (cDNA2).

The SSH process entails two rounds of hybridization followed by two PCR reactions. Poly $\mathrm{A}^{+}$mRNA is isolated from total RNA and reverse transcribed to give a double-stranded cDNA pool. The cDNAs are digested by a restriction enzyme into fragments of a narrow size range. For cDNA subtraction, the tester pool is divided into two equal parts and different adaptors are ligated to $5^{\prime}$ ends of each fragment (Ad1 and Ad2R). In the first set of hybridizations, an excess of driver cDNA without linkers is denatured and hybridized separately with each tester cDNA pool and the reactions are allowed to proceed under identical conditions. Among species present at the same concentration in the tester, those present in similar or higher levels in the driver will form duplexes at a faster rate than those whose concentration in the driver is lower. In the second hybridization, both samples are mixed together with addition of excess single-stranded driver for further subtraction. The resulting pool is a mixture of single-stranded, double-stranded with only one linker, double-stranded like the original pools, and double-stranded with both linkers corresponding to the tester-specific fragments. After the hybridization reaction, filling the ends of the adaptors allows the creation of templates to be amplified by PCR. The cDNA possessing the same kind of adaptor on both sides will form a hairpin structure, thus preventing the amplification of this type of product. Those duplexes in which the two strands have different adaptors are exponentially amplified in the PCR reactions. The resulting final PCR product is enriched in tester-specific cDNAs. The products are then ligated into vectors that are used to transform Escherichia coli. The clones are characterized to confirm their specificity. To identify genes that are down-regulated in the sample used as the tester, a reverse SSH is carried out by switching the samples used as tester and driver.

After the subtraction, specificity must be confirmed because the resulting PCR product is only enriched in differentially expressed cDNAs. To screen a large number of candidates, the cDNAs are arrayed on nitrocellulose, nylon membrane, or glass and hybridized with probes made from the original tissues. In the case of very low expression genes, the use of subtracted probes may prove to be useful because relative abundance is normalized during the suppressive PCR amplifications. Finally, Northern blot analysis or quantitative PCR standardized to the level of a stable known housekeeping gene are needed to precisely measure the levels in differential expression between the samples.

The following materials are available as a kit from Clontech Laboratories (PCR-Select cDNA Subtraction Kit).

\section{MATERIALS}

1. Oligonucleotides:

cDNA synthesis primer: 5'-TTTTGTACAAGCTT $_{30} \mathbf{3}^{\prime}$

(GTAC-Rsa I, AAGCTT-Hind III restriction enzyme digestion sites)

Adaptor 1 (Ad1):

5'-CTAATACGACTCACTATAGGGCTCGAGCGGCCGCCCGGGCAGGT-3'

$3^{\prime}$-GGCCCGTCCA-5'

Adaptor 2R (Ad2R):

5'-GTAATACGACTCACTATAGGGCAGCGTGGTGGTCGCGGCCGAGGT-3'

3'-GCCGGCTCCA-5'

PCR Primer 1 (P1): 5'-CTAATACGACTCACTATAGGGC-3'

Nested PCR Primer 1 (NP1): 5'-TCGAGCGGCCGCCCGGGCAGGT-3'

Nested PCR Primer 2R (NP2R): 5'-AGCGTGGTCGCGGCCGAGGT-3'

Control Primers: Glyceraldehyde 3-phosphate dehydrogenase (G3PDH)

G3PDH 5' Primer: 5'-ACCACAGTCCATGCCATCAC $-3^{\prime}$ 


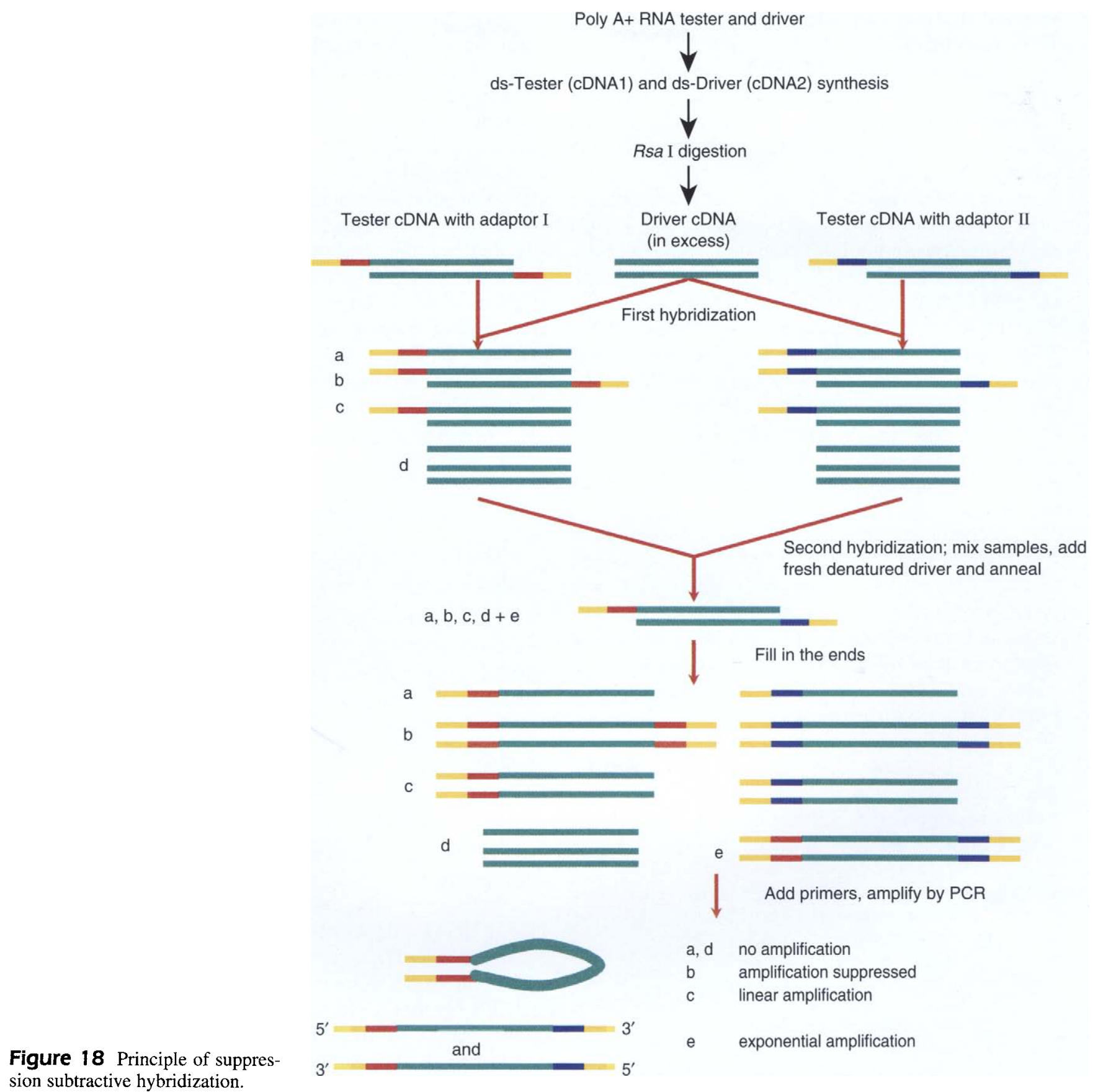

G3PDH 3' Primer: 5'-TCCACCACCCTGTTGCTGTA-3'

2. Blocking solution: A mixture of the cDNA synthesis primer, nested primers (NP1 and NP2R), and their respective complementary oligonucleotides (2 $\mathrm{mg} \mathrm{ml}^{-1}$ each).

3. Buffers and enzymes:

a. First-strand synthesis: AMV (avian myeloblastosis virus) reverse transcriptase (20 units $\mu l^{-1}$ ), $5 \mathrm{X}$ first-strand buffer $(250 \mathrm{mM}$ Tris- $\mathrm{HCl}$ [pH 8.5], $4.0 \mathrm{mM} \mathrm{MgCl}_{2}, 150 \mathrm{mM} \mathrm{KCl}, 5 \mathrm{mM}$ Dithiothreitol). b. Second-strand synthesis: $20 \mathrm{X}$ second-strand enzyme cocktail (DNA polymerase I, 6 units $\mu \mathrm{l}^{-1}$, RNAse $\mathrm{H}, 0.25$ units $\mu \mathrm{l}^{-1}, E$. coli DNA ligase, 1.2 units $\left.\mu \mathrm{l}^{-1}\right), 5 \mathrm{X}$ second-strand buffer $(500 \mathrm{mM}$ $\mathrm{KCl}, 50 \mathrm{mM}$ ammonium sulfate, $25 \mathrm{mM} \mathrm{MgCl}_{2}$, $0.75 \mathrm{mM}$ beta-nicotinamide adenine dinucleotide (B-NAD), $100 \mathrm{mM}$ Tris-HCl [pH 7.5], $0.25 \mathrm{mg} \mathrm{ml}^{-1}$ bovine serum albumin [BSA] and T4 DNA polymerase [ 3 units $\left.\mu 1^{-1}\right]$ ).

c. Endonuclease digestion: 10X Rsa I restriction buffer, $100 \mathrm{mM}$ Bis Tris propane- $\mathrm{HCl}[\mathrm{pH} 7.0]$, $100 \mathrm{mM} \mathrm{MgCl}$, $1 \mathrm{mM}$ DTT, $(100 \mathrm{mM}$ Bis Tris 
propane- $\mathrm{HCl}$ [pH 7.0], $100 \mathrm{mM} \mathrm{MgCl} 2,1 \mathrm{mM}$ DTT) Rsa I (10 units $\left.\mu \mathrm{l}^{-1}\right)$.

d. Adaptor ligation: T4 DNA ligase (400 units $\mu \mathrm{l}^{-1}$; contains $3 \mathrm{mM}$ ATP), $5 \mathrm{X}$ DNA ligation buffer (250 mM Tris- $\mathrm{HCl}$ [pH 7.8], $50 \mathrm{mM} \mathrm{MgCl}, 10 \mathrm{mM}$ DTT, $\left.0.25 \mathrm{mg} \mathrm{ml}^{-1} \mathrm{BSA}\right), 10 \mu \mathrm{M}$ adaptor $1,10 \mu \mathrm{M}$ adaptor $2 \mathrm{R}$.

e. Hybridization: $4 \mathrm{X}$ hybridization buffer (4M NaCl, $200 \mathrm{mM}$ HEPES [pH 8.3], $4 \mathrm{mM}$ cetyltrimethyl ammonium bromide $\mathrm{CTAB}$ ), dilution buffer (20 mM HEPES-HCl [pH 8.3], $50 \mathrm{mM} \mathrm{NaCl}$, 0.2 mM EDTA [pH 8.0]).

f. PCR amplification: use of Advantage cDNA PCR mix (Clontech) is strongly recommended. Alternatively, normal Taq DNA polymerase can be used, but five additional PCR cycles will be needed in both the primary and secondary PCR, and the use of manual hot start or hot start wax beads is strongly recommended to reduce nonspecific DNA synthesis.

g. General reagents: dNTP $\operatorname{mix}(10 \mathrm{mM}$ each dATP, dCTP, dGTP, dTTP), 20X EDTA/glycogen mix (0.2M EDTA; $1 \mathrm{mg} \mathrm{ml}^{-1}$ glycogen), 4M $\mathrm{NH}_{4} \mathrm{OAc}$, sterile $\mathrm{H}_{2} \mathrm{O}$. DNA size marker Hae III digest of bacteriophage $\phi X 174$, RNAse-free DNAse (MessageClean Kit, GenHunter Corporation, MA).

h. General solutions: $80 \%$ and $96 \%$ ethanol, phenol:chlorophorm:isoamyl alcohol (25:24:1), 50X TAE electrophoresis buffer (242 $\mathrm{g}$ Tris base, $57.1 \mathrm{~g}$ glacial acetic acid, $37.2 \mathrm{~g} \mathrm{Na}_{2}$ EDTA. $2 \mathrm{H}_{2} \mathrm{O}$, add $\mathrm{H}_{2} \mathrm{O}$ to $1 \mathrm{~L}$ ).

Radioisotope $[\alpha-32 \mathrm{P}] \mathrm{dCTP} \quad\left(10 \mathrm{mCi} \mathrm{ml}^{-1}\right.$ $3000 \mathrm{Ci} / \mathrm{mmol}$ ) usage is optional.

Note: All the cycling parameters are given for the Perkin-Elmer DNA Thermal Cycler 9600/2400 (Perkin-Elmer). The cycling parameters must be optimized for each PCR machine.

\section{METHODS}

\section{Isolation of poly(A)+ RNA from Sample Tissue or Cultured Cells}

SSH requires high-quality, intact, and pure mRNA for the synthesis of high-quality cDNA. It is more efficient to isolate total RNA from the samples that will be used as tester and driver and then isolate poly $(\mathrm{A})^{+}$ RNA from the total RNA. The general procedure for total RNA isolation can be found in the book by Sambrook et al. (1989). The total RNA is then used to isolate poly $(\mathrm{A})^{+} \mathrm{RNA}$ by using a commercial mRNA purification kit (such as polyA Spin isolation kit [New England Biolabs Inc., MA]).
It is highly recommended to examine the total and poly (A)+ RNA integrity by electrophoresing samples on a formaldehyde denaturing agarose/ethidium bromide gel. Total mammalian RNA typically shows two bright bands, which correspond to ribosomal $28 \mathrm{~S}$ and $18 \mathrm{~S}$ at $\sim 4.5$ and $1.9 \mathrm{~kb}$, respectively, and the ratio of band intensities are $\sim 1.5-2.5: 1$. Mammalian poly(A) ${ }^{+}$ RNA appears as a smear from approximately $0.5-12 \mathrm{~kb}$ with weak ribosomal bands. It is also recommended to remove the contaminating DNA to improve the efficiency of SSH by treating the RNA samples with RNAse-free DNAse (the MessegeClean Kit can efficiently remove the DNA without degrading the RNA samples).

The following protocol is recommended for generating a subtracted library from $2-4 \mu \mathrm{g}$ of poly(A) ${ }^{+}$ RNA. Using a PCR block for all reactions is strongly recommended.

\section{First-Strand cDNA Synthesis}

The following procedure should be applied to each individual tester and driver poly(A)+ RNA sample.

1. For each tester and driver sample (name the tubes cDNA1 and cDNA2, respectively) combine the following components into a sterile $0.5 \mathrm{ml}$ microcentrifuge tube (do not use a polystyrene tube): $2-4 \mu \mathrm{g}$ poly(A) ${ }^{+} \mathrm{RNA}$ to $2-4 \mu \mathrm{l}, 10 \mu \mathrm{M}$ cDNA synthesis primer to $1 \mu \mathrm{l}$. If necessary add sterile $\mathrm{H}_{2} \mathrm{O}$ to a final volume of $5 \mu$ l.

2. Heat a thermal cycler to $70^{\circ} \mathrm{C}$ and incubate tubes for $2 \mathrm{~min}$ at $70^{\circ} \mathrm{C}$.

3. Cool the tubes on ice for $2 \mathrm{~min}$ and briefly centrifuge the tubes.

4. In each tube, add $2 \mu \mathrm{l} 5 \mathrm{X}$ first-strand buffer, $1 \mu \mathrm{l}$ dNTP (deoxyribonucleotide-triphosphate) mix, $1 \mu \mathrm{l}$ sterile $\mathrm{H}_{2} \mathrm{O}, 1 \mu \mathrm{l}$ AMV reverse transcriptase (20 units $\mu l^{-1}$ ). (Optional: to monitor the progress of cDNA synthesis, dilute $1 \mu 1$ of [ $\left.\alpha-{ }^{32} \mathrm{P}\right] \mathrm{dCTP}$ [10 $\mathrm{mCi}$ $\left.\mathrm{ml}^{-1} 3000 \mathrm{Ci} / \mathrm{mmol}\right]$ with $9 \mu \mathrm{l}$ of $\mathrm{H}_{2} \mathrm{O}$, and replace $\mathrm{H}_{2} \mathrm{O}$ with $1 \mu \mathrm{l}$ of diluted label.)

5 . Gently vortex and briefly centrifuge the tubes.

6. Incubate the tubes at $42^{\circ} \mathrm{C}$ for $1.5 \mathrm{~h}$ in an air incubator to avoid any evaporation.

7. Place the tubes on ice to terminate first-strand cDNA synthesis and immediately proceed to secondstrand synthesis.

\section{Second-Strand cDNA Synthesis}

1. Combine the following components into the firststrand cDNA sample tubes (from previous section, Step 7): $48.4 \mu \mathrm{H}_{2} \mathrm{O}, 16 \mu \mathrm{l} 5 \mathrm{X}$ second-strand buffer, 
1.6 $\mu \mathrm{l}$ dNTP mix, $4 \mu \mathrm{l} 20 \mathrm{X}$ second-strand enzyme cocktail.

2. Mix the contents and briefly centrifuge the tubes. The final volume should be $80 \mu \mathrm{l}$.

3. Incubate the tubes at $16^{\circ} \mathrm{C}$ for $30 \mathrm{~min}$ in a thermal cycler.

4. Add $4 \mu \mathrm{l}$ of $20 \mathrm{X}$ EDTA/glycogen mix to terminate the second-strand synthesis reaction.

5 . Add $100 \mu \mathrm{l}$ of phenol:chlorophorm:isoamyl alcohol $(25: 24: 1)$.

6 . Vortex thoroughly, and centrifuge the tubes at $14,000 \mathrm{rpm}$ for $10 \mathrm{~min}$ at room temperature.

7. Carefully remove the top aqueous layer and place in a sterile $0.5 \mathrm{ml}$ microcentrifuge tube. Discard the interphase and lower phase.

8. Add $100 \mu \mathrm{l}$ of chlorophorm:isoamyl alcohol (24:1) to the aqueous layer.

9. Repeat Steps 6 and 7.

10. Add $40 \mu \mathrm{l}$ of $4 \mathrm{M} \mathrm{NH} \mathrm{N}_{4} \mathrm{OAc}$ and $300 \mu \mathrm{l}$ of $95 \%$ ethanol.

11. Without waiting, vortex the tubes thoroughly and precipitate the pellet at $14,000 \mathrm{rpm}$ for $20 \mathrm{~min}$ at room temperature.

12. Remove the supernatant carefully (if you used $[\alpha-32 \mathrm{P}] \mathrm{dCTP}$ check for presence of the pellet using a Geiger counter).

13. Wash the pellet with $500 \mu \mathrm{l}$ of $80 \%$ ethanol without excessively disturbing the pellet.

14. Air-dry the pellet for $\sim 10 \mathrm{~min}$ to evaporate the remaining ethanol.

15. Dissolve the pellet in $50 \mu 1 \mathrm{H}_{2} \mathrm{O}$.

16. Transfer $6 \mu \mathrm{l}$ from each sample to fresh tubes and store these samples at $-20^{\circ} \mathrm{C}$.

\section{Rsa I Digestion}

The $R s a$ I digestion step is performed to generate shorter, blunt-ended double-strand (ds) cDNA fragments that are optimal for subtractive hybridization and also necessary for the adaptor ligation step later in the protocol.

The following protocol should be performed for each experimental ds tester (cDNA1) and driver (cDNA2) cDNA:

1. Add the following reagents into each tube: $43.5 \mu \mathrm{l}$ ds cDNA, $5 \mu$ l 10X Rsa I restriction buffer, $1.5 \mu \mathrm{l} R s a \mathrm{I}$ (10 units $\mu \mathrm{l}^{-1}$ ).

2. Mix by vortexing and centrifuge briefly.

3. Incubate at $37^{\circ} \mathrm{C}$ for $1.5 \mathrm{hr}$.

4. Set aside $5 \mu \mathrm{l}$ of the digested mixture and analyze on a $2 \%$ agarose/EtBr gel run in $1 \times$ TAE buffer along with undigested cDNA (from previous section, Step 16) to determine the efficiency of $R s a$ I digestion.
The ds cDNA preparation appears as a smear, and after $R s a$ I digestion, the average cDNA size is smaller.

Note: During this procedure continue the digestion reaction and terminate it only after you are satisfied with the result of your digestion.

5. Add $2.5 \mu \mathrm{l}$ of $20 \mathrm{X}$ EDTA/glycogen mix to terminate the reaction.

6. Add $50 \mu \mathrm{l}$ of phenol:chloroform:isoamyl alcohol (25:24:1) and vortex thoroughly.

7. Centrifuge the tubes at $14,000 \mathrm{rpm}$ for $10 \mathrm{~min}$ to separate the phases.

8. Remove the top aqueous layer and place in a clean $0.5 \mathrm{ml}$ tube.

9. Add $50 \mu \mathrm{l}$ of phenol:chloroform (24:1) and vortex thoroughly.

10. Centrifuge the tubes at $14,000 \mathrm{rpm}$ for $10 \mathrm{~min}$ to separate phases.

11. Transfer the top aqueous layer to a clean $0.5 \mathrm{ml}$ tube.

12. Add $25 \mu \mathrm{l}$ of $4 \mathrm{M} \mathrm{NH}_{4} \mathrm{OAc}$ and $187.5 \mu \mathrm{l}$ of $95 \%$ ethanol.

13. Without waiting, vortex the mixture thoroughly and precipitate the pellet at $14,000 \mathrm{rpm}$ for $20 \mathrm{~min}$ at room temperature.

14. Remove the supernatant carefully and gently overlay $200 \mu \mathrm{l}$ of $80 \%$ ethanol on the pellet.

15. Centrifuge at $14,000 \mathrm{rpm}$ for $5 \mathrm{~min}$ and remove the supernatant carefully (if you used $[\alpha-32 \mathrm{P}] \mathrm{dCTP}$, check for presence of the pellet using a Geiger counter).

16. Air-dry the pellet for about $10 \mathrm{~min}$ to evaporate the remaining ethanol.

17. Dissolve the pellet in $5.5 \mu \mathrm{l}$ of $\mathrm{H}_{2} \mathrm{O}$ (the pellets can be stored at $-20^{\circ} \mathrm{C}$ at this step).

\section{Adaptor Ligation}

It is strongly recommended that subtraction be performed in both directions for each tester/driver cDNA pair. The forward subtraction reaction is designed to enrich for differentially expressed sequences present in tester (cDNA1) but not in driver (cDNA2); reverse subtraction is designed to enrich differentially expressed sequences present in driver (cDNA2) but not in tester (cDNA1). Both forward and reverse subtracted cDNAs will be useful as probes for differential screening of the resulting tester cDNA library. Tester $\mathrm{cDNAs}$ are ligated separately to Ad1 (tester 1-1 and 2-1) and Ad2R (tester 1-2 and 2-2). It is highly recommended that a third ligation of both adaptors 1 and $2 \mathrm{R}$ to the tester cDNAs (unsubtracted tester control) be performed and used as a negative control for subtraction.

Important Note: The adaptors are not ligated to the driver cDNA; for example, if you are using $R s a$ I digested cDNA 1 as a tester for subtraction, Rsa I digested driver cDNA2 should not be used for ligation, and vice versa. 
1. Label four $0.5 \mathrm{ml}$ tubes as tester $1-1$, tester $1-2$ (for cDNA1 as a tester), tester 2-1, and tester 2-2 (for cDNA2 as a tester).

2. Dilute $1 \mu \mathrm{l}$ of each $R s a$ I digested tester cDNA 1 and cDNA2 from the previous section, Step 17, with $5 \mu \mathrm{l}$ sterile $\mathrm{H}_{2} \mathrm{O}$.

3. Prepare a master ligation mix by combining the following reagents in a $0.5 \mathrm{ml}$ tube: $3 \mu \mathrm{l}$ sterile $\mathrm{H}_{2} \mathrm{O}$, $2 \mu \mathrm{l} 5 \mathrm{X}$ ligation buffer, $1 \mu \mathrm{l}$ adenosine triphosphate (ATP) $(3 \mathrm{mM}), 1 \mu \mathrm{l} \mathrm{T} 4$ DNA ligase (400 units $\left.\mu \mathrm{l}^{-1}\right)$.

4. For each tester cDNA mixture, the reagents are combined in a $0.5 \mathrm{ml}$ tube in the following order:

\begin{tabular}{lcc} 
Component & $\begin{array}{c}\text { Tube 1, Tester 1-1 } \\
(\mu \mathrm{l})\end{array}$ & $\begin{array}{c}\text { Tube 2, Tester 1-2 } \\
(\mu 1)\end{array}$ \\
\hline Diluted tester cDNA & 2 & 2 \\
Adaptor Adl $(10 \mu \mathrm{M})$ & 2 & - \\
Adaptor Ad2R $(10 \mu \mathrm{M})$ & - & 2 \\
Master ligation mix & 6 & 6 \\
\hline Final volume & 10 & 10 \\
$\quad$ aThe same setup also is used for Tester 2-1 and Tester 2-2. \\
$\quad$ Tester 1-1: cDNA1 ligated to adaptor 1; Tester 1-2: cDNA1 ligated to \\
adaptor 2 \\
$\quad$ Tester 2-1: cDNA2 ligated to adaptor 1; Tester 2-2: cDNA2 ligated to \\
adaptor 2
\end{tabular}

The two adaptors provide different PCR primer annealing sites. This way, two tester cDNA populations from the same cDNA are created with different adaptors.

5. In a fresh microcentrifuge tube, mix $2 \mu 1$ of tester 1-1 (from tube 1) and $2 \mu \mathrm{l}$ of tester 1-2 (from tube 2). This will be your unsubtracted tester control. Do the same reaction for tester 2-1 and 2-2.

6. Centrifuge the tubes briefly and incubate at $16^{\circ} \mathrm{C}$ overnight.

7. Stop the ligation reaction by adding $1 \mu \mathrm{l}$ of $0.2 \mathrm{M}$ EDTA.

8. Heat the samples at $72^{\circ} \mathrm{C}$ for $5 \mathrm{~min}$ to inactivate the ligase (use a thermal block) and briefly centrifuge the tubes. The adaptor ligation step is now completed for tester cDNAs 1-1 and 1-2.

9. Remove $1 \mu$ of each unsubtracted tester control and dilute in $1 \mathrm{ml}$ of $\mathrm{H}_{2} \mathrm{O}$. These samples will be used for PCR amplification.

\section{Analysis of Ligation Efficiency}

It is recommended to perform the following PCR experiment to verify that at least $25 \%$ of the cDNAs have adaptors at both ends.

1. Dilute $1 \mu \mathrm{l}$ of each ligated $\mathrm{cDNA}$ (from previous section, Step 4) into $200 \mu \mathrm{l}$ of $\mathrm{H}_{2} \mathrm{O}$.

2. Set up the PCR reaction as follows:

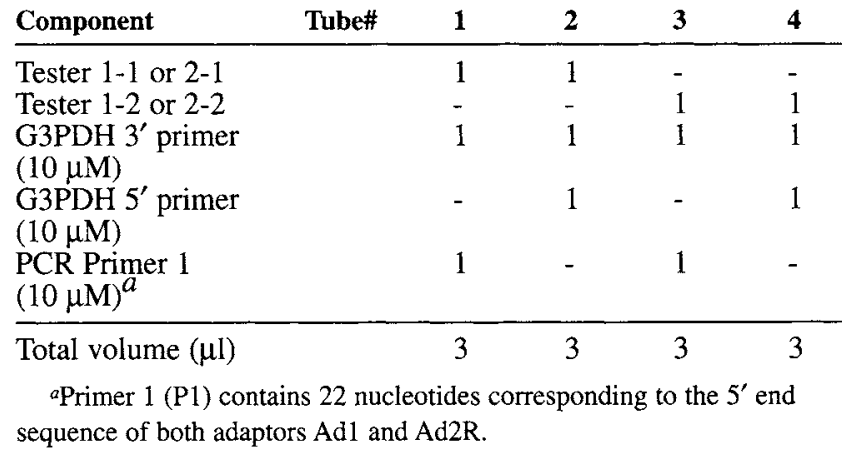

3. Prepare a master mix for all the tubes plus one additional tube. For each reaction, combine the reagents in the order:

\begin{tabular}{lc} 
Reagent & Amount per reaction tube $(\mu \mathrm{l})$ \\
\hline Sterile $\mathrm{H}_{2} \mathrm{O}$ & 18.5 \\
10X PCR reaction buffer & 2.5 \\
dNTP mix $(10 \mathrm{mM})$ & 0.5 \\
50X Advantage cDNA PCR mix & 0.5 \\
\hline Total volume & 22
\end{tabular}

Alternatively, normal Taq DNA polymerase can be used instead of Advantage cDNA PCR polymerase chain reaction mix, but additional PCR cycles will be needed.

4. Mix the reagents thoroughly and briefly centrifuge the tubes.

5. Aliquot $22 \mu \mathrm{l}$ of master mix into each reaction tube from Step 2.

6. Put $50 \mu$ l of mineral oil into each tube (if oil-free thermal cycler is used, omit this step).

7. Incubate the reaction mixture in a thermal cycler at $75^{\circ} \mathrm{C}$ for $5 \mathrm{~min}$ to extend the adaptors.

8. Without removing the samples from the cycler, immediately commence 20 cycles of $94^{\circ} \mathrm{C}, 30$ seconds; $65^{\circ} \mathrm{C}, 30$ seconds; $68^{\circ} \mathrm{C}, 2.5 \mathrm{~min}$.

9. Analyze $5 \mu \mathrm{l}$ from each reaction on a $2 \%$ agarose $/ \mathrm{EtBr}$ gel run in $1 \mathrm{X}$ TAE buffer.

If the product is not visible after 20 cycles, an additional five cycles can be carried out and step 9 can be repeated.

The PCR reactions with G3PDH $3^{\prime}$ and primer 1 primers where tester 1-1 (adaptor 1 ligated) or tester 1-2 (adaptor 2R ligated) are used as the template should generate $0.75 \mathrm{~kb}$ PCR product (tubes 1 and 3 ). The PCR reactions with G3PDH $3^{\prime}$ and $5^{\prime}$ primers where tester 1-1 or tester 1-2 are used as the template should generate $0.4 \mathrm{~kb}$ PCR product (tubes 2 and 4). The efficiency of adaptor 1 and adaptor $2 \mathrm{R}$ ligation is determined by comparing the relative intensities of the bands for the products of tube 2 to 1 and tube 4 to 3 , respectively.

Note: If the result of the ligation is not satisfactory, you should repeat the ligation with fresh samples before proceeding to the hybridization steps. 


\section{First Hybridization}

During first hybridization, hybridization kinetics lead to equalization and enrichment of differentially expressed sequences. In the first hybridization, each tester $(1-1,1-2$, etc.) cDNA is hybridized with excess driver cDNA. Single-strand cDNAs are enriched for differentially expressed sequences because nontarget cDNAs present in the tester and driver cDNA form hybrids.

1. For each tester sample, combine the reagents in $0.5 \mathrm{ml}$ tubes in the following order:

Important note: $4 \mathrm{X}$ hybridization buffer should be warmed to room temperature before use.

\begin{tabular}{|c|c|c|}
\hline Component & $\begin{array}{l}\text { Hybridization } \\
\text { sample } 1(\mu \mathrm{l})\end{array}$ & $\begin{array}{l}\text { Hybridization } \\
\text { sample } 2(\mu \mathrm{I})\end{array}$ \\
\hline $\begin{array}{l}R s a \text { I digested driver cDNA } \\
\text { (from } R s a \text { I Digestion section, } \\
\text { Step 17) }\end{array}$ & 1.5 & 1.5 \\
\hline $\begin{array}{l}\text { Ad1-ligated tester } 1-1^{a} \text { (from } \\
\text { Adaptor Ligation section, } \\
\text { Step 4) }\end{array}$ & 1.5 & - \\
\hline $\begin{array}{l}\text { Ad2R-ligated tester } 1-2 \text { (from } \\
\text { Adaptor Ligation section, } \\
\text { Step 4) }\end{array}$ & - & 1.5 \\
\hline $4 \mathrm{X}$ hybridization buffer & 1 & 1 \\
\hline Final volume & 4 & 4 \\
\hline
\end{tabular}

2. Put one drop of mineral oil into each tube and centrifuge briefly.

3. Incubate the samples in a thermal cycler at $98^{\circ} \mathrm{C}$ for $1.5 \mathrm{~min}$ and then at $68^{\circ} \mathrm{C}$ for $8-12 \mathrm{hr}$.

4. Proceed immediately to the second hybridization step.

Important note: Do not remove the hybridization samples from the thermal cycler for longer than necessary to add fresh driver for the second hybridization.

\section{Second Hybridization}

In the second hybridization, two samples from the first hybridization are mixed together and excess driver cDNA is added. New hybrid molecules consisting of differentially expressed cDNAs with different adaptors on each end that can be used for PCR are formed.

The following steps should be repeated for each experimental driver cDNA:

1. Add the following reagents in a tube: $1 \mu \mathrm{l}$ driver cDNA (from Rsa I Digestion section, Step 17), 4X hybridization buffer, $2 \mu$ sterile $\mathrm{H}_{2} \mathrm{O}$. Mix gently and briefly centrifuge the contents of the tube.

2. Place $1 \mu \mathrm{l}$ of this mixture in a $0.5 \mathrm{ml}$ microcentrifuge tube and overlay with one drop of mineral oil. Incubate in a thermal cycler at $98^{\circ} \mathrm{C}$ for $1.5 \mathrm{~min}$.
3. To this tube of freshly denatured driver cDNA, add hybridized sample 1 and hybridized sample 2 (prepared in First Hybridization section, Step 4).

Note: For efficient hybridization, the two hybridization samples should be mixed together only in the presence of freshly denatured driver. To achieve this, using a $20 \mu \mathrm{l}$ micropipettor draw the hybridization sample $2(4 \mu \mathrm{l})$ into the pipette tip, provide a little air space in the tip, and then draw freshly denatured driver cDNA $(1 \mu \mathrm{l})$ without mixing the samples. Then add the whole content of the tip into the hybridization sample $1(4 \mu \mathrm{l})$.

4. Mix the entire mixture and briefly centrifuge the tube.

5. Incubate the hybridization reaction in a thermal cycler at $68^{\circ} \mathrm{C}$ for $14-16 \mathrm{hr}$.

6. Add $200 \mu$ of dilution buffer to the tube and mix well by pipetting.

7. Incubate the hybridization reaction in a thermal cycler at $68^{\circ} \mathrm{C}$ for $7 \mathrm{~min}$.

8. Store the sample at $-20^{\circ} \mathrm{C}$.

\section{PCR Amplification for the Selection of Differentially Expressed cDNAs}

In this step differentially expressed cDNAs are selectively amplified. Adaptors Ad1 and Ad2R contain the sequence for PCR primer P1 at their $5^{\prime}$ ends. Therefore it is essential to extend the $5^{\prime}$ ends of the adaptors. All the cycling parameters are given for the Perkin-Elmer DNA Thermal Cycler 9600/2400 (Perkin-Elmer). The cycling parameters must be optimized for each PCR machine. Use of Advantage cDNA PCR mix (Clontech) is strongly recommended. Alternatively, normal Taq DNA polymerase can be used, but five additional PCR cycles will be needed in both the primary and secondary PCR and the use of manual hot start or hot start wax beads is strongly recommended to reduce nonspecific DNA synthesis. Each amplification should have at least four reactions: 1) forward subtracted tester cDNAs; 2) unsubtracted tester control; 3) reverse subtracted tester cDNAs; and 4) unsubtracted driver control for the reverse subtraction.

\section{Primary PCR}

1. Aliquot $1 \mu \mathrm{l}$ of each diluted cDNA into an appropriately labeled tube (each subtracted sample from Second Hybridization section, Step 8 and the corresponding diluted unsubtracted tester control from Adaptor Ligation section, Step 9).

2. Prepare a master mix sufficient for all the reaction tubes by combining the following reagents in order (amount per reaction): $19.5 \mu \mathrm{H}_{2} \mathrm{O}, 2.5 \mu \mathrm{l} 10 \mathrm{X}$ PCR buffer, $0.5 \mu \mathrm{l} \mathrm{dNTP} \operatorname{mix}(10 \mathrm{mM}), 1 \mu \mathrm{l}$ PCR primer 
$\mathrm{P} 1(10 \mu \mathrm{M}), 0.5 \mu \mathrm{l}$ Advantage cDNA polymerase mix for a total volume of $24 \mu$ l.

3. Mix the reagents well and briefly centrifuge the tube.

4. Aliquot $24 \mu \mathrm{l}$ of master mix into each reaction tube from Step 1.

5. Overlay $50 \mu$ l of mineral oil into each tube (if oil-free thermal cycler is used, omit this step).

6. Incubate the reaction mixture in a thermal cycler at $75^{\circ} \mathrm{C}$ for $5 \mathrm{~min}$ to extend the adaptors.

7. Immediately commence one cycle of $94^{\circ} \mathrm{C}$, 25 seconds and 27 cycles of $94^{\circ} \mathrm{C}, 30$ seconds; $66^{\circ} \mathrm{C}$, 30 seconds; $72^{\circ} \mathrm{C}, 1.5 \mathrm{~min}$.

8. Analyze $8 \mu \mathrm{l}$ from each reaction on a $2 \%$ agarose/EtBr gel run in $1 \mathrm{X}$ TAE buffer.

\section{Secondary PCR}

1. Dilute each primary PCR mixture in $27 \mu \mathrm{l}$ of $\mathrm{H}_{2} \mathrm{O}$.

2. Aliquot $1 \mu \mathrm{l}$ of each diluted primary PCR product mixture from Step 1 into appropriately numbered tubes.

3. Prepare a master mix for the secondary PCR enough for all the reaction tubes by combining the following reagents in order (amount per reaction): $18.5 \mu \mathrm{l}$ $\mathrm{H}_{2} \mathrm{O}, 2.5 \mu \mathrm{l}$ 10X PCR buffer, $0.5 \mu \mathrm{l}$ dNTP mix $(10 \mathrm{mM})$, $1 \mu \mathrm{l}$ nested PCR primer NP1 $(10 \mu \mathrm{M}), 1 \mu \mathrm{l}$ nested PCR primer NP2R $(10 \mu \mathrm{M}), 0.5 \mu 150 \mathrm{X}$ Advantage cDNA polymerase mix for a total volume of $24 \mu \mathrm{l}$.

4. Mix the reagents well and briefly centrifuge the tube.

5. Aliquot $24 \mu \mathrm{l}$ of master mix into each reaction tube from Step 2.

6. Overlay $50 \mu \mathrm{l}$ of mineral oil into each tube (if oil-free thermal cycler is used, omit this step).

7. Immediately commence 12 cycles of $94^{\circ} \mathrm{C}$, 30 seconds; $68^{\circ} \mathrm{C}, 30$ seconds; $72^{\circ} \mathrm{C}, 1.5 \mathrm{~min}$.

8. Analyze $8 \mu \mathrm{l}$ from each reaction on a $2 \%$ agarose/ EtBr gel run in $1 \mathrm{X}$ TAE buffer.

9. Store reaction products at $4^{\circ} \mathrm{C}$ for the Thymine/ Adenine (T/A) cloning procedure. Freezing and thawing the PCR products decreases the efficiency of cloning.

The PCR mixture is now enriched for differentially expressed sequences.

The secondary PCR products of subtracted samples usually look like smears. If no product is observed after 12 cycles, increase the number of cycles cautiously because too many cycles increase the background.

\section{Subtraction Efficiency Test}

To compare the abundance of known cDNAs before and after subtraction and to analyze the efficiency of subtraction, a quick PCR-based assay can be performed. PCR is performed for a ubiquitously expressed gene (such as G3PDH) between the two RNA sources under comparison. Figure 19 shows the results of the subtraction efficiency test for the forward and reverse subtracted libraries. In a successfully subtracted mixture, G3PDH abundance is reduced. In the subtracted samples the G3PDH PCR product should be observed 5-15 cycles later than the unsubtracted samples. In the unsubtracted sample, G3PDH product is observed after 18-23 cycles.

\section{PCR Analysis of Subtraction}

1. Dilute the subtracted and unsubtracted (unsubtracted tester control 1 and 2) secondary PCR products tenfold in $\mathrm{H}_{2} \mathrm{O}$.

2. Combine the following reagents in $0.5 \mathrm{ml}$ microcentrifuge tubes in the following order:

\begin{tabular}{lcc} 
Tube no. & $\mathbf{1}(\mu \mathrm{l})$ & $\mathbf{2}(\mu \mathrm{l})$ \\
\hline $\begin{array}{l}\text { Diluted subtracted cDNA } \\
\text { (2nd PCR product) }\end{array}$ & 1 & - \\
$\begin{array}{l}\text { Diluted unsubtracted control } \\
\text { (2nd PCR product) }\end{array}$ & - & 1 \\
G3PDH 5' primer $(10 \mu \mathrm{M})$ & 1.2 & 1.2 \\
G3PDH 3' primer $(10 \mu \mathrm{M})$ & 1.2 & 1.2 \\
Sterile $\mathrm{H}_{2} \mathrm{O}$ & 22.4 & 22.4 \\
10× PCR reaction buffer & 3 & 3 \\
dNTP mix (10 mM) & 0.6 & 0.6 \\
50× Advantage cDNA PCR Mix & 0.6 & 0.6 \\
\hline Total volume & 30 & 30
\end{tabular}

3. Mix and briefly centrifuge the tubes.

4. Overlay with one drop of mineral oil (if oil-free thermal cycler is used, omit this step).

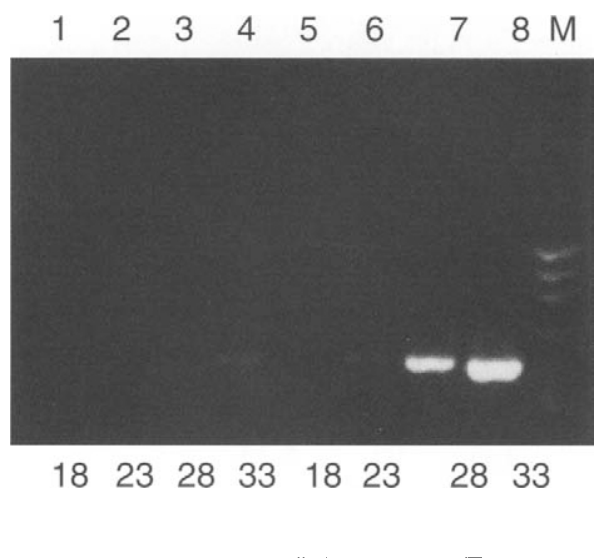

Figure 19 Analysis of subtraction efficiency test: Tester complementary deoxyribonucleic acid (CDNA) was prepared from MCF7 breast carcinoma cells transfected with BRCA1 cDNA carrying expression vector and driver cDNA was prepared from MCF7 cells transfected only with the expression vector. M: HaeIII digested $\phi X 174$ (Sigma) $(1.3,1.1,0.9,0.6,0.3 \mathrm{~kb})$. Secondary polymerase chain reaction (PCR) was performed on forward subtracted experimental cDNA (lanes 1-4) and unsubtracted tester control for forward subtraction (lanes 5-8) with G3PDH $5^{\prime}$ and $3^{\prime}$ primers. 
5. Use the following thermal cycling program for 18 cycles; $94^{\circ} \mathrm{C}, 30$ seconds; $60^{\circ} \mathrm{C}, 30$ seconds; $68^{\circ} \mathrm{C}$, 2 min.

6. Remove $5 \mu \mathrm{l}$ from each reaction, place it in a clean tube, and store on ice. Put the rest of the reaction back into the thermal cycler for three more cycles.

7. Repeat Step 6 three times (i.e., remove $5 \mu \mathrm{l}$ after 23,28 , and 33 cycles).

8. Examine the $5 \mu \mathrm{l}$ samples (the aliquots that were removed from each reaction after $18,23,28$, and 33 cycles) on a $2.0 \%$ agarose $/ \mathrm{EtBr}$ gel (Figure 19 ).

A gene known to be expressed in the tester RNA but not in the driver RNA can be used as a positive control, and the previous procedure can be performed with the primers specific to this gene. This cDNA should become enriched by the subtraction procedure.

\section{Cloning of Subtracted cDNAs}

The uncloned subtracted cDNA mixture can be used to screen various libraries such as genomic, cDNA, YAC, or cosmid. The subtracted cDNA library can be made by subcloning the PCR products (secondary PCR products from the Secondary PCR section) into plasmid vectors using conventional cloning procedures.

The following details describe a method that is commonly applied for cloning the subtracted cDNAs.

\section{T/A Cloning}

1. Use $3 \mu 1$ of the secondary PCR product (from Secondary PCR section, Step 7) for cloning with a T/Abased system, such as the Advantage PCR Cloning Kit (Clontech) or Promega PGEM-T Easy Vector system, according to the manufacturer's protocols.

2. After ligating the secondary PCR products into the vector, the library is transformed into a bacterial strain such as $E$. coli JM109 strain of high-efficiency competent cells $\left(1 \times 10^{8} \mathrm{cfu} / \mu \mathrm{g}\right.$ DNA $)$ by heat shock treatment. Alternatively, electrocompetent cells can be transformed by electroporation using $1.8 \mathrm{kV}$ pulse with a pulser (BioRad Gene Pulser).

Other host strains can be used, but they should be compatible with blue/white color screening and standard ampicillin selection.
It is important to optimize the cloning efficiency because low efficiency will cause high background and low representation of the subtracted clones.

3 . The transformed cells are plated onto agar plates containing X-gal $\left(50 \mathrm{mg} \mathrm{l}^{-1}\right)$ and IPTG (isopropylD-thiogaloctopyranoside) (100 $\mathrm{mM})$.

4. Recombinant white clones are randomly picked and inoculated in $100 \mu 1$ of ampicillin-containing LBmedium in 96-well microtiter plates.

5. Bacteria should be allowed to grow at $37^{\circ} \mathrm{C}$ for at least $4 \mathrm{hr}$ before insert amplification or alternatively grown overnight.

\section{cDNA Insert Analysis by PCR}

It is recommended to check for the presence of cDNA inserts in a small number of colonies first and then analyze a large number of colonies. PGEM-T Easy Vector has universal T7 and SP6 primers that can be used to amplify inserts cloned into this plasmid. The bacterial culture can be used directly for PCR amplification of the cDNA inserts.

1. Prepare a master mix for 100 PCR reactions:

\begin{tabular}{lc} 
& Per reaction $(\mu \mathrm{L})$ \\
\hline $10 \times \mathrm{PCR}$ reaction buffer & 2 \\
$\mathrm{MgCl}_{2}(25 \mathrm{mM})$ & 1.2 \\
$\mathrm{SP6}$ Primer $(20 \mathrm{pmol} / \mu \mathrm{l})^{a}$ & 1 \\
$\mathrm{~T} 7 \mathrm{primer}(20 \mathrm{pmol} / \mu \mathrm{l})^{a}$ & 1 \\
$\mathrm{dNTP} \mathrm{Mix}(10 \mathrm{mM})$ & 0.4 \\
$\mathrm{H}_{2} \mathrm{O}$ & 13.2 \\
Taq DNA Polymerase & 0.2 \\
\hline Total volume & 19.0
\end{tabular}

${ }^{a}$ Alternatively nested PCR primer 1 and $2 \mathrm{R}$ can be used in PCR amplification of the inserts.

2. Aliquot $19 \mu \mathrm{l}$ of the master mix into each tube.

3. Transfer $1 \mu \mathrm{l}$ of each bacterial culture (from Step 5) to each tube containing the master mix.

4. Perform PCR in an oil-free thermal cycler with the following conditions: 1 cycle: $94^{\circ} \mathrm{C}, 2 \mathrm{~min}$ and then 30 cycles: $94^{\circ} \mathrm{C}, 1 \mathrm{~min} ; 55^{\circ} \mathrm{C}, 1 \mathrm{~min} ; 72^{\circ} \mathrm{C}, 1 \mathrm{~min}$.

5. Analyze $5 \mu \mathrm{l}$ from each reaction on a $2.0 \%$ agarose/EtBr gel (Figure 20).

It is important to detect clones carrying cDNA inserts before proceeding to the differential screening procedure. The number of differentially expressed

Figure 20 Insert screening analysis. White colonies were randomly picked from forward subtracted library of MCF7 breast carcinoma cells ectopically expressing the $B R C A 1$ gene and polymerase chain reaction amplified with T7-Sp6 primers.

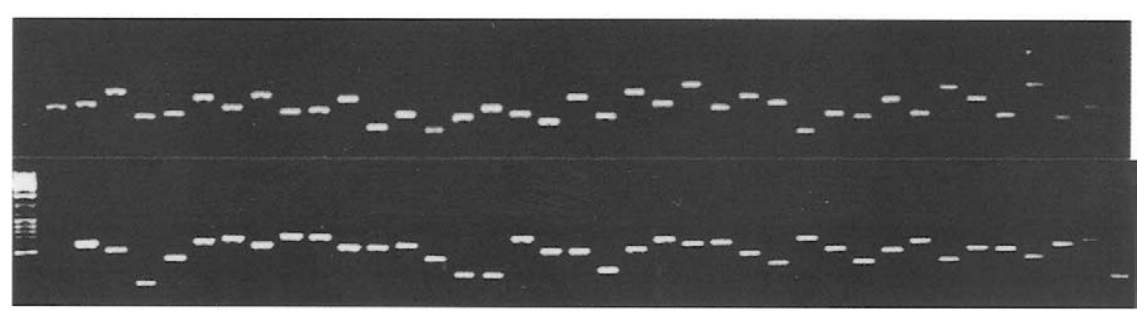


genes can differ between the two tissue types under comparison. This effects the number of independent clones obtained from the subtracted samples. The subtraction and the cloning efficiencies are other important parameters that directly influence the colony numbers. In general, 500-1000 colonies are recommended for the screening procedure.

\section{Differential Screening of the Subtracted Library}

Several factors are responsible for the sensitivity of the whole experiment. Screening the subtracted library is very important for the sensitivity. The PCRbased SSH technology greatly enriches the differentially expressed genes, but the subtracted samples may still have some cDNAs common to both the tester and driver samples. Differential screening of subtracted library with subtracted probes will increase the sensitivity for detecting true differentially expressed sequences and decrease the chance of getting false-positive transcripts, which may still be present in the subtracted library.

The following differential screening technique will greatly increase the sensitivity for detecting the differentially expressed sequences, even those that correspond to low-abundance differentially expressed mRNAs. The subtracted library is hybridized with forward and reverse subtracted cDNA probes. The reverse subtracted probe is made by performing the subtraction with original tester cDNA as a driver and the driver as a tester. Truly differentially expressed sequences will hybridize only with the forward subtracted probe, and clones that hybridize with reverse subtracted probe are considered to be background. To screen the subtracted library, the PCR products of the cDNA clones can be arrayed as dots on nylon filters.

\section{Preparation of cDNA Dot Blots by Arraying the PCR Products}

\section{MATERIALS}

PCR products from each clone, $0.6 \mathrm{~N} \mathrm{NaOH}, 0.5 \mathrm{M}$ Tris- $\mathrm{HCl}[\mathrm{pH} 7.5], 2 \mathrm{X} \mathrm{SSC}(300 \mathrm{mM} \mathrm{NaCl}$ and $30 \mathrm{mM}$ $\mathrm{Na}_{3}$. Citrate. $2 \mathrm{H}_{2} \mathrm{O}$ [pH 7.0]) are required.

\section{METHODS}

For high-throughput analysis, it is easier to use a 96-well microtiter plate for formatting the PCR products as arrays.
1. Transfer $5 \mu \mathrm{l}$ of PCR product of each cDNA clone in a 96-well microtiter plate and add $5 \mu \mathrm{l}$ of freshly made $0.6 \mathrm{~N} \mathrm{NaOH}$ to denature the DNA for hybridization.

2. Mix the combination by slowly spinning the plate.

3. Transfer 1 or $2 \mu \mathrm{l}$ of each mixture to a nylon membrane by using a micropipettor. This process can be accomplished by using a 96-well replicator or alternatively with a multichannel micropipettor.

4. Make at least two identical blots for hybridization with subtracted and reverse subtracted probes (see the Adaptor Ligation section).

5. Neutralize the blots for $2-4 \mathrm{~min}$ in $0.5 \mathrm{M}$ Tris$\mathrm{HCl}(\mathrm{pH} 7.5)$ and wash in $2 \mathrm{X} \mathrm{SSC}$.

6. Cross-link cDNA on the membrane by baking the blots at $80^{\circ} \mathrm{C}$ for 2 hours or alternatively use a ultraviolet UV crosslinking device (such as Strategene's UV Stratalinker) under $120 \mathrm{~mJ}$.

\section{Preparation of cDNA Probes}

The arrays prepared from the previous step are hybridized with forward and reverse subtracted cDNA probes. Before the hybridization step, the adaptors from the forward and reverse subtracted cDNA probes should be removed to reduce the background that can be caused by these sequences on the arrayed subtracted library. Therefore the subtracted cDNA mixtures are digested with restriction enzymes that have specific restriction sites in the adaptor sequences. Some of the following materials are also available as a kit from Clontech Laboratories (PCR-Select Differential Screening Kit).

\section{MATERIALS}

The following enzymes can be obtained from New England BioLabs: Rsa I, Eag I, and Sma I restriction enzymes (10 unit $\left.\mu \mathrm{l}^{-1}\right), 10 \mathrm{X}$ restriction buffer 4 (for Rsa I, Eag I), and 10X restriction buffer 3 (for Sma I).

1. Each of the forward and reverse subtracted secondary PCR products $(\sim 40 \mu \mathrm{l})$ should be purified before the restriction enzyme digestion using a PCR purification kit or alternatively using a silica matrixbased purification system. You can set up more than one reaction to ensure enough cDNA as a probe for the hybridization steps.

2. After purification adjust the volume of both products to $28 \mu$ l with $\mathrm{H}_{2} \mathrm{O}$. Remove $3 \mu \mathrm{l}$ of this sample for agarose gel electrophoresis. Make sure that the concentration of PCR products in each sample is the same.

3. To remove the adaptor sequences add $3 \mu \mathrm{l} 10 \mathrm{X}$ restriction buffer 4 and $1.5 \mu \mathrm{l} R s a \mathrm{I}$. 
Note: To control the restriction reaction efficiency you can use a plasmid that contains an $R s a$ I restriction site as a control. In separate tubes, mix $3 \mu \mathrm{I}$ of each restriction digest sample (From Step 3) and add $25 \mathrm{ng}$ of plasmid DNA.

4. Incubate the tubes for $1 \mathrm{hr}$ at $37^{\circ} \mathrm{C}$.

5. While this digestion reaction is still in incubation, electrophorese $3 \mu \mathrm{l}$ of each undigested $\mathrm{cDNA}, 3 \mu \mathrm{l}$ of each digested cDNA, and $3 \mu$ of each digested cDNA plus digested plasmid on a $2 \%$ agarose/EtBR gel.

6. After analyzing the first digestion efficiency, add $1 \mu \mathrm{l}$ of Sma I into each reaction (from Step 4) and incubate for another hour at room temperature.

7. Add $61 \mu \mathrm{l}$ of $\mathrm{H}_{2} \mathrm{O}, 10 \mu \mathrm{l}$ of $10 \mathrm{X}$ restriction buffer 3 , and $1 \mu \mathrm{l}$ of Eag I to each tube and incubate the tubes for another hour at $37^{\circ} \mathrm{C}$.

8. Remove the adaptors from the cDNA using a PCR purification kit or alternatively using a silica matrixbased purification system.

\section{Random Primer Labeling of CDNA Probes}

The tester and driver cDNA probes can be labeled with radioisotope $[\alpha-32 \mathrm{P}] \mathrm{dCTP} \quad\left(10 \mathrm{mCi} \mathrm{ml}^{-1}\right.$ $3000 \mathrm{Ci} / \mathrm{mmol}$ ) by using a commercially available random primer labeling kit. Tester-specific subtracted probe (forward subtracted probe) and driver-specific subtracted probe (reverse subtracted probe) are used for differential screening hybridization.

\section{Differential Hybridization with Forward and Reverse Subtracted Probes}

In this section, the ${ }^{32} \mathrm{P}-\mathrm{labeled}$ probes will be hybridized to the subtracted clones arrayed on nylon membranes.

\section{MATERIALS}

The required reagents include the following:

^ Hybridization solution: $0.5 \mathrm{M}$ phosphate buffer (pH 7.2), 7\% SDS, 1 mM EDTA (pH 8.0), 1\% BSA, $10 \mu \mathrm{g} \mathrm{ml}^{-1}$ sheared salmon sperm DNA (added after boiling).

\ Blocking solution: $2 \mathrm{mg} \mathrm{ml}^{-1}$ of NP1, NP2R, cDNA synthesis primers, and their complementary oligonucleotides.

^ Wash buffers: Low-stringency (2X SSC/0.5\% SDS) and high-stringency $(0.2 \mathrm{X} \mathrm{SSC} / 0.5 \%$ SDS $)$ washing buffers, prewarmed to $68^{\circ} \mathrm{C}$.

- Hybridization probes: 20X SSC $(3 \mathrm{M} \mathrm{NaCl}$ and $0.3 \mathrm{M} \mathrm{Na}_{3}$ Citrate. $\left.2 \mathrm{H}_{2} \mathrm{O}[\mathrm{pH} 7.0]\right), 50 \mu \mathrm{l}$ of sheared salmon sperm DNA $\left(10 \mu \mathrm{g} \mathrm{ml}^{-1}\right), 10 \mu \mathrm{l}$ blocking solution, purified probe (at least $10^{7} \mathrm{cpm}$. per $100 \mathrm{ng}$ of subtracted cDNA).

\section{METHODS}

1. Prepare a prehybridization solution for each membrane:

a. Mix $50 \mu \mathrm{l}$ of $20 \mathrm{X} \mathrm{SSC}, 50 \mu \mathrm{l}$ of sheared salmon sperm DNA $\left(10 \mu \mathrm{g} \mathrm{ml}^{-1}\right)$ and $10 \mu \mathrm{l}$ of blocking solution.

b Boil this mixture for $5 \mathrm{~min}$, then chill on ice.

c. Combine the chilled mixture with $5 \mathrm{ml}$ of hybridization solution (prewarmed to $68^{\circ} \mathrm{C}$ ).

2. Place each membrane in the prehybridization solution prepared in Step 1.

3. Prehybridize for $2-4 \mathrm{hr}$ with continuous agitation at $68^{\circ} \mathrm{C}$.

Note: It is important that you add blocking solution to the prehybridization solution because subtracted probes contain the same adaptor sequences as arrayed clones.

4. Prepare hybridization probes:

a. Mix $50 \mu \mathrm{l}$ of $20 \mathrm{X} \mathrm{SSC}, 50 \mu \mathrm{l}$ of sheared salmon sperm DNA $\left(10 \mu \mathrm{g} \mathrm{ml}^{-1}\right)$, and $10 \mu \mathrm{l}$ blocking solution and purified probe.

b. Boil the probe for $5 \mathrm{~min}$, then chill on ice.

c. Add the chilled probe solution to the hybridization solution.

5. Hybridize overnight with continuous agitation at $68^{\circ} \mathrm{C}$.

Note: Avoid adding the probe directly to the membrane.

6. Prepare low-stringency ( $2 X$ SSC/ $0.5 \%$ SDS) and high-stringency $(0.2 \mathrm{X} \mathrm{SSC} / 0.5 \% \mathrm{SDS})$ washing buffers, prewarmed to $68^{\circ} \mathrm{C}$.

7. Wash membranes with low-stringency buffer $\left(4 \times 20 \mathrm{~min}\right.$ at $\left.68^{\circ} \mathrm{C}\right)$, then wash with high-stringency buffer $\left(2 \times 20 \mathrm{~min}\right.$ at $\left.68^{\circ} \mathrm{C}\right)$

8. Expose the membrane to X-ray film (Kodak) overnight with an intensifying screen at $-70^{\circ} \mathrm{C}$. (You can expose the membrane to $\mathrm{X}$-ray film for varying lengths of time.)

\section{RESULTS}

\section{Interpretation of Hybridization Results}

The results of a differential screening experiment are shown in Figure 21. These results show different types of hybridization:

1. Clones hybridized with the forward subtracted probe but not with the reverse subtracted probe (e.g., C3, G3, and E1) are most likely to correspond to differentially expressed mRNAs that are worth pursuing.

2. Clones that are hybridized equally to both subtracted probes (e.g., E2 and F1) do not represent 


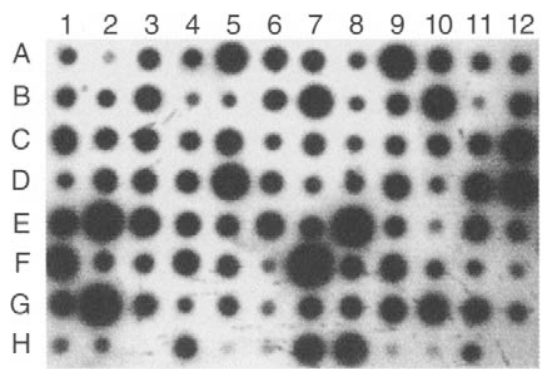

A

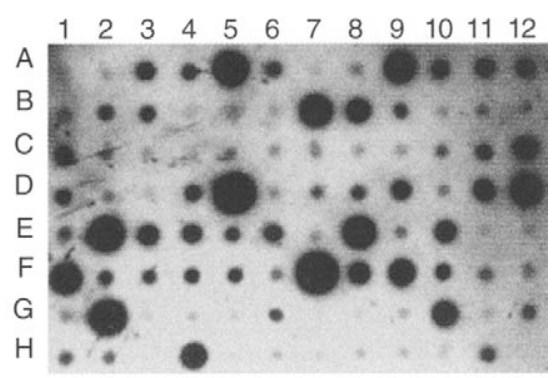

B

Figure 21 Differential screening of suppression subtractive hybridization (SSH)-selected complementary deoxyribonucleic acid (cDNA)-clones with forward (A) and reverse (B) subtracted probes. Selected cDNA inserts were PCR-amplified from the forward subtracted cDNA library, enriched for BRCA1 upregulated sequences, spotted in two identical membranes, and hybridized with [ $\alpha-32 \mathrm{P}] \mathrm{dCTP}-$ labeled forward (Tester; MCF7 breast carcinoma cells ectopically expressing BRCA1) or reverse subtracted (Tester; MCF7 cells transfected only with the vector that was used to clone BRCA1) cDNA probes. Rows A-H: test CDNA samples, H3: negative PCR control, H5-H6: cDNA1 and H9-10: cDNA2 as negative control cDNAs, H7-8: BRCA1, H12: NaOH + water). For example, E2 cDNA showed no significant increase (1.76-fold), but C3 cDNA (zinc finger protein, $\mathrm{LZKl}$ ) displayed sevenfold increase. The signal intensities were measured by a phosphorimager (Atalay et al., 2002).

differentially expressed mRNAs and do not need further analysis.

3. Clones that are hybridized equally to both subtracted probes, but where the intensity of the hybridization signals is different: If the intensity difference is $\geq$ fivefold (e.g., E3), the clone probably corresponds to differentially expressed mRNAs and should be analyzed further. If the intensity difference is $\leq$ threefold (e.g., F2), it is more likely the result of a random fluctuation in the efficiency of the forward and reverse subtractions.

4. Clones that are not hybridized with either of the subtracted probes (e.g., A2 and F12) usually represent nondifferentially expressed cDNAs present in the PCR select library.

\section{Confirmation of Differential Screening Results}

There are several ways to confirm the differential expression of the candidate clones identified by differential screening, such as Northern blot hybridization, Virtual Northern blot analysis, or quantitative-reverse transcription PCR. Northern blot analysis is a direct way to analyze the expression between two samples populations under comparison. It not only shows the expression difference but also the amount of transcript present in the samples and the full transcript size of the gene. This analysis requires at least $2 \mu \mathrm{g}$ of poly $\mathrm{A}^{+}$ RNA.

Virtual Northern blots can be used if the amount of starting poly $\mathrm{A}^{+} \mathrm{RNA}$ is not sufficient for Northern blot analysis. To carry out a Virtual Northern blot, the SMART PCR cDNA synthesis kit (Clontech) can be used to make cDNAs from the poly $\mathrm{A}^{+}$RNA sample, which can be transferred onto a nylon membrane. Although it is an informative method, for some cDNA clones it may give multiple bands.

RT-PCR analysis is extremely sensitive for detecting the expression differences between the samples and can be performed either as a semi-quantitative or quantitative method. To use this approach, the candidate CDNA clones should be sequenced and specific PCR primers should be designed. However, it is not a technique for high-throughput analysis because it is time consuming.

\section{Sequence Analysis of Differentially Expressed Clones}

To determine the nature of the transcripts, sequence analysis should be carried out from the $5^{\prime}$-end of the selected transcripts. The sequences can then be analyzed by using the freely available databases such as Genbank/EMBL and Expressed Sequence Tag (EST). The result of the sequence analysis may assign each transcript to a known tissue-specific transcript or a transcript known to be expressed preferentially in target tissue or a novel transcript with known or recognizable motifs. The last case may also provide clues to whether the sequence is a member of a protein family.

\section{DISCUSSION}

SSH PCR is a sophisticated cDNA subtraction method to enrich and isolate differentially expressed genes. SSH accomplishes normalization and subtraction by taking advantage of the different rates of hybridization of cDNA strands for different genes depending on 
their abundance level and the degree of (differential) expression (Desai et al., 2000). Effective enrichment of a target gene by SSH PCR is determined by the concentration ratio between tester and driver and is more efficient the higher this value (Ji et al., 2002). SSH is generally better suited for the identification of sizable differences (approximately fivefold or greater) in rare transcripts, but arrays can detect smaller differences. The two techniques are complementary if the goal is a comprehensive detection of even small differences.

$\mathrm{SSH}$, unfortunately, can be used only for pairwise treatment comparisons and must be replicated with the tester and driver reversed to identify gene expression changes in both directions. It also is not a quantitative method for measuring expression differences. SSH is best used for identifying genes that are completely absent, rather than expressed less abundantly, in the driver sample (Moody, 2001). In general, one of the major problems associated with specific cellular characterization is the low amount of sample. However, problems associated with tissues in small quantities can be solved by a restricted PCR amplification step prior to cDNA subtraction. When the amount of starting material is limited it is possible to start with only a few ng of total RNA and produce enough double-stranded cDNA of both tester and driver to subtract two specific cell populations by using PCR technology (SMART PCR cDNA Synthesis Kit, Clontech).

There are some other methods such as DNA chip/ microarray, which is a very powerful method when used to identify differentially regulated genes on a genomewide scale (Kurian et al., 1999) but may not be able to detect transcripts present in the mRNA (or cDNA) populations in low quantity, making SSH a useful complementary approach (Yang et al., 1999).

SSH has been widely used in the study of cell differentiation (Du et al., 2001; Hofsaess and Kapfhammer, 2003) and development in animals (Cobellis et al., 2001; Fellenberg et al., 2003; Lee et al., 2002; Yao et al., 2003) and cancer diagnosis in humans because differentially expressed genes are often important in disease pathogenesis (Atalay et al., 2002; Kostic and Shaw, 2000; Wang et al., 2001; Zhou et al., 2002). It has even been used for the study of rice development (Liu et al., 2001) and algae (Zhang et al., 2002). SSH is applicable to many studies in which the cDNAs derived from the differentially expressed genes of a particular tissue of cell type are being analyzed. The method reviewed here is a powerful technology that expands the study of gene expression from single genes to the genomic level. The genomic information from different species continues to be sequenced at great speed and SSH technology is one of the approaches that will be very much in demand for comparing the genomic structure of cells in the coming years. This type of genomic technique and the rapidly developing bioinformatics field will enable researchers to investigate gene expression and gain a better understanding of the genomic regulation of biologic processes that will have important applications in human and animal health and improvement of livestock production.

\section{References}

Atalay, A., Crook, T., Ozturk, M., and Yulug, I.G. 2002. Identification of genes induced by BRCA1 in breast cancer cells. Biochem. Biophys. Res. Commun. 299:839-846.

Cobellis, G., Missero, C., Simionati, B., Valle, G., and Di Lauro, R. 2001. Immediate early genes induced by $\mathrm{H}-\mathrm{R}$ as in thyroid cells. Oncogene 20:2281-2290.

Davis, M.M., Cohen, D.I., Nielsen, E.A., Steinmetz, M., Paul, W.E., and Hood, L. 1984. Cell-type specific cDNA probes and the murine I region: The localization and orientation of $\mathrm{Ad}$ alpha. Proc. Natl. Acad. Sci. USA. 81:2194-2198.

Desai, S., Hill, J., Trelogan, S., Diatchenko, L., Siebert, P.D. 2000. Identification of differentially expressed genes by suppression subtractive hybridization. In: Functional Genomics: A Practical Approach. Hunt, S.P., and Livesey, F.J. (eds), pp. 81-112. Oxford, Oxford University Press, 81-112.

Diatchenko, L., Lau, Y.F., Campbell, A.P., Chenchik, A., Moqadam, F., Huang, B., Lukyanov, S., Lukyanov, k., Gurskaya, N., Sverdlov, E.D., and Siebert, P.D. 1996. Suppression subtractive hybridization: A method for generating differentially regulated or tissue-specific cDNA probes and libraries. Proc. Natl. Acad. Sci. USA. 93:6025-6030.

Diatchenko, L., Lukyanov, S., Lau, Y.F., and Siebert, P.D. 1999. Suppression subtractive hybridization: A versatile method for identifying differentially expressed genes. Methods Enzymol. 303:349-380.

Du, Z., Cong, H., and Yao, Z. 2001. Identification of putative downstream genes of Oct-4 by suppression-subtractive hybridization. Biochem. Biophys. Res. Commun. 282:701-706.

Duguid, J.R., and Dinauer, M.C. 1990. Library subtraction of in vitro cDNA libraries to identify differentially expressed genes in scrapie infection. Nucleic Acids Res. 18:2789-2792.

Fellenberg, J., Dechant, M.J., Ewerbeck, V., and Mau, H. 2003. Identification of drug-regulated genes in osteosarcoma cells. Int. J. Cancer 105:636-643.

Hedrick, S.M., Cohen, D.I., Neilson, E.A., and Davis, M.M. 1984. Isolation of cDNA clones encoding T cell-specific membraneassociated proteins. Nature 308:149-153.

Hofsaess, U., and Kapfhammer, J.P. 2003. Identification of numerous genes differentially expressed in rat brain during postnatal development by suppression subtractive hybridization and expression analysis of the novel rat gene rMMS2. Brain Res. Mol. Brain Res. 113:13-27.

Ji, W., Wright, B.M., Cai, L., Flament, A., and Lindpaintner, K. 2002. Efficacy of SSH PCR in isolating differentially expressed genes. BMC Genomics 3:12.

Kostic, C., and Shaw, P.H. 2000. Isolation and characterization of sixteen novel p53 response genes. Oncogene 19:3978-3987.

Kurian, K.M., Watson, C.J., and Wyllie, A.H. 1999. DNA chip technology. J. Pathol. 187:267-271.

Lee, K.F., Yao, Y.Q., Kwok, K.L., Xu, J.S., and Yeung, W.S. 2002. Early developing embryos affect the gene expression patterns in the mouse oviduct. Biochem. Biophys. Res. Commun. 292:564-570. 
Li, P., and Rossman; T.G. 2001. Genes upregulated in lead-resistant glioma cells reveal possible targets for lead-induced developmental neurotoxicity. Toxicol. Sci. 64:90-99.

Liu, C., Zhang, L., Shao, Z.M., Beatty, P., Sartippour, M., Lane, T.F., Barsky, S.H., Livingston, E., and Nguyen, M. 2002. Identification of a novel endothelial-derived gene EG-1. Biochem. Biophys. Res. Commun. 290:602-612.

Liu, J., Liu, J., Yuan, Z., Qian, X., Qian, M., and Yang, J. 2001. Isolation and identification of genes expressed differentially in rice inflorescence meristem with suppression subtractive hybridization. Chinese Sci. Bull. 46:98-101.

Moody, D.E. 2001. Genomics techniques: An overview of methods for the study of gene expression. J. Anim. Sci. 79 (E. Suppl.):E128-E135.

Sambrook, J., Fritsch, E.F., and Manistis, T., 1989. Molecular Cloning: A Laboratory Manual, 2nd ed. New York, Cold Spring Harbor Laboratory.

Sargent, T.D., and Dawid, I.B., 1983. Differential gene expression in the gastrula of Xenopus laevis. Science 222:135-139.

Stassar, M.J., Devitt, G., Brosius, M., Rinnab, L., Prang, J., Schradin, T., Simon, J., Petersen, S., Kopp-Schneider, A., and Zoller, M. 2001. Identification of human renal cell carcinoma associated genes by suppression subtractive hybridization. $B r . J$. Cancer 85:1372-1382.

Uchijima, M., Raz, E., Carson, D.A., Nagata, T., and Koide, Y., 2001. Identification of immunostimulatory DNA-induced genes by suppression subtractive hybridization. Biochem. Biophys. Res. Commun. 286:688-691.
Wang, Q., Yang, C., Zhou, J., Wang, X., Wu, M., and Liu, Z. 2001. Cloning and characterization of full-length human ribosomal protein L15 cDNA which was overexpressed in esophageal cancer. Gene 263:205-209.

Wang, Z., and Brown, D.D. 1991. A gene expression screen. Proc. Natl. Acad. Sci. USA. 88:11505-11509.

Yang, G.P., Ross, D.T., Kuang, W.W., Brown P.O., and Weigel, R.J. 1999. Combining SSH and cDNA microarrays for rapid identification of differentially expressed genes. Nucleic Acids Res. 27:1517-1523.

Yao, Y.Q., Xu, J.S., Lee, W.M., Yeung, W.S., and Lee, K.F. 2003. Identification of mRNAs that are up-regulated after fertilization in the murine zygote by suppression subtractive hybridization. Biochem. Biophys. Res. Commun. 304:60-66.

Ye, S.Q. 2004. Serial analysis of gene expression in human diseases. In Hayat, M.A. (ed) Immunohistochemistry and in situ Hybridization of Human Carcinomas. Vol. 1. San Diego: Elsevier Academic, 85-98.

Zhang, X.N., Qu, Z.C., Wan, Y.Z., Zhang, H.W., and Shen, D.A. 2002. Application of suppression subtractive hybridization (SSH) to cloning differentially expressed cDNA in Dunaliella salina (Chlorophyta) under hyperosmotic shock. Plant. Mol. Biol. Report 20:49-57.

Zhou, J., Wang, H., Lu, A., Hu, G., Luo, A., Ding, F., Zhang, J., Wang, X., Wu, M., and Liu, Z. 2002. A novel gene, NMES1, downregulated in human esophageal squamous cell carcinoma. Int. J. Cancer 101:311-316. 